\title{
A Peroxidase Gene Promoter Induced by Phytopathogens and Methyl Jasmonate in Transgenic Plants
}

\author{
Mark D. Curtis, ${ }^{1}$ Anne L. Rae,${ }^{2}$ Anca G. Rusu, ${ }^{1,2}$ Stuart J. Harrison, ${ }^{1}$ and John M. Manners ${ }^{1,2}$ \\ ${ }^{1}$ Cooperative Research Centre for Tropical Plant Pathology, John Hines Building, The University of Queen- \\ sland, Brisbane 4072, Australia, ${ }^{2} \mathrm{CSIRO}$, Division of Tropical Agriculture, Cunningham Laboratory, St. \\ Lucia 4067, Australia \\ Received 29 July 1996. Accepted 17 December 1996.
}

The expression of two closely related peroxidase isogenes, Shpx6a and Shpx6b, of the legume Stylosanthes humilis was studied using isogene-specific reverse transcriptase PCR techniques. Results indicated that transcripts of both genes were rapidly induced following inoculation with the fungal pathogen Colletotrichum gloeosporioides, wounding and treatment with the defense regulator methyl jasmonate (MeJA). In contrast, treatment of leaves of $S$. humilis with abscisic acid (ABA) and salicylic acid (SA) did not induce transcripts of either isogene. A genomic clone containing the Shpx6b gene was isolated and 594 bp of $5^{\prime}$ sequence upstream of the translation start was fused in frame to the coding region of the uidA reporter gene and introduced into tobacco. Expression from the Shpx6b promoter in transgenic plants was determined by histochemical staining and quantitative assays of $\beta$-glucuronidase (GUS). In transgenic tobacco, GUS expression was detected in cotyledons, vascular cells of young leaves, anthers, pollen, and the stigma and style. Wounding of the tobacco plants produced very localized GUS staining. Much more extensive staining for GUS was observed following inoculation of tobacco leaves with conidia of the fungal pathogen Cercospora nicotianae and the inoculation of wound sites with mycelium of the Oomycete pathogen Phytophthora parasitica var. nicotianae. Treatment of mature leaves with methyl jasmonate induced GUS activity while treatment with $\mathrm{ABA}, \mathrm{SA}$, and $\mathrm{H}_{2} \mathrm{O}_{2}$ had no effect. A similar strong induction of GUS activity was measured in young transgenic seedlings germinated on MeJA while some, but much weaker, induction of GUS activity was observed in seedlings treated with SA. The sequence of the promoter contained motifs homologous to putative cis elements in other plant genes responsive to MeJA. The Shpx6b gene is the first plant peroxidase gene shown to be induced by both microbial pathogens and MeJA and its promoter will be useful for investigations of signaling processes during fungal infection and

Corresponding author: J. M. Manners; E-mail: j.manners@tpp.uq.edu.au

Present address of M. D. Curtis: Cold Spring Harbor Laboratory, P.O. Box 100, Cold Spring Harbor, NY 11724, U.S.A.

Nucleotide and/or amino acid sequence data can be accessed as GSDB accession no. L37790. for the expression of foreign gene products at infection sites.

Additional keyword: Nicotiana tabacum.

The induction of plant peroxidases appears to be an early event in plant-microbe interactions (Cook et al. 1995; Harrison et al. 1995). Peroxidases (EC 1.11.1.7; donor: hydrogenperoxide oxidoreductase) are believed to be involved in several plant defense responses including lignification (Walter 1992), the cross linking of cell wall proteins (Bradley et al. 1992), suberization, and wound healing (Sherf et al. 1993), and in the production of antimicrobial radicals (Kobayashi et al. 1994; Peng and Kuc 1992). Several investigators have shown that fungal and Oomycete pathogens can specifically induce the production of new isoforms of peroxidases in their plant hosts (e.g., Irving and Kuc 1990; Kerby and Somerville 1989; Ye et al. 1990). However, the signaling and regulatory processes underlying the early induction of plant peroxidase genes during microbial infection are largely unknown.

Hybridization methods using cDNA probes have frequently been used to show the differential expression of distinct families of plant peroxidase genes during pathogen attack (e.g., Harrison et al. 1995; Thordal-Christensen et al. 1992). One of the problems encountered in studies of plant peroxidases is the large number of closely related peroxidase genes found in plants. Peroxidases in plants form a superfamily of broadly related genes that can be subdivided on the basis of amino acid (aa) and nucleotide (nt) sequence homologies into isogene families (e.g., Ross et al. 1995; Tyson 1992). The high nucleotide sequence homology of peroxidase isogenes makes it difficult to study the expression of any single member of an isogene family using DNA hybridization probes. Methods that permit the study of individual peroxidase isogenes include the use of isogene-specific oligonucleotide primers for reverse transcriptase (RT) PCR analysis of mRNA populations and the cloning and characterization of promoter regions from specific isogenes in transgenic plant systems. An aim of our research has been to characterize the mechanisms underlying the rapid induction of specific peroxidase isogenes during fungal infection of the legumes Stylosanthes spp.

Previously we have reported four distinct cDNA clones of peroxidases from the tropical legume Stylosanthes humilis (Harrison et al. 1995). These cDNAs each represented isogene 
families that did not cross-hybridize and were differentially regulated during infection by Colletotrichum gloeosporioides. Using Northern (RNA) hybridization techniques, it was demonstrated that transcripts homologous to the peroxidaseencoding cDNA Shpx6 (GSDB Accession no. L36110), were induced early in the infection process at a time preceding fungal penetration. It was proposed that induction of the Shpx6 peroxidase may have a role in restricting fungal penetration in this host-pathogen interaction (Harrison et al. 1995). Southern analysis of genomic DNA of $S$. humilis suggested that there were likely to be two closely related isogenes encoding Shpx6-like peroxidases (Harrison et al. 1995). A genomic homologue of the Shpx6 cDNA was subsequently isolated from a genomic library of $S$. humilis and its nucleotide sequence determined (GSDB Accession no. L37790; Curtis et al. 1995). This cationic peroxidase gene has $83 \%$ nucleotide sequence homology in the coding region to the cDNA Shpx6. We propose that the two Shpx6 isogenes be termed Shpx6a (L36110) and Shpx6b (L37790). The transcripts of these two isogenes would not have been differentiated in previous Northern hybridization experiments (Harrison et al. 1995). In this study we describe the expression of the Shpx6b isogene using gene-specific RT-PCR analysis in $S$. humilis and using promoter-reporter gene fusions in transgenic tobacco. Results indicate that this specific isogene is induced by microbial

A

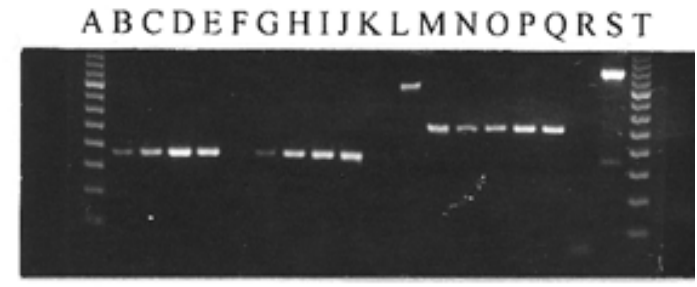

B

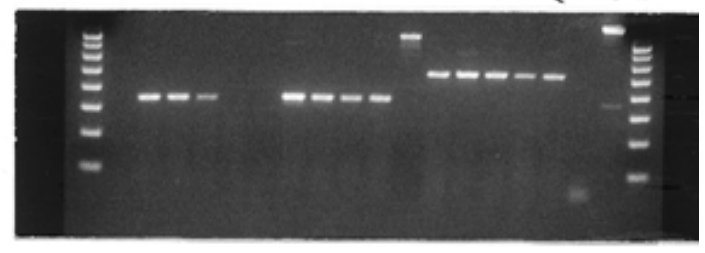

Fig. 1. RT-PCR analysis showing the expression of mRNAs corresponding to Shpx6a and Shpx6b in young leaves of Stylosanthes humilis following inoculation with Colletotrichum gloeosporioides (a) and following wounding (b). Lanes A and T contained the 100-bp marker ladder, Lanes B to F correspond to RT-PCR products derived from transcripts of Shpx6a, Lanes G to K correspond to RT-PCR products derived from transcripts of Shpx6b. Lane L corresponds to a PCR product derived from genomic DNA using the primers specific for Shpx6b. Lanes $\mathrm{M}$ to $\mathrm{Q}$ correspond to RT-PCR products derived from transcripts of a constitutively expressed CAD gene as a positive control, Lane $\mathrm{R}$ is a $\mathrm{H}_{2} \mathrm{O}$ control in the RT-PCR reaction, and $\mathrm{S}$ corresponds to $\mathrm{PCR}$ products derived from genomic DNA using the CAD primers. In (a), lanes B, G, and $\mathrm{M}$ correspond to RT-PCR reaction products derived from RNA preparations obtained at $0 \mathrm{~h}$ postinoculation; $\mathrm{C}, \mathrm{H}$, and $\mathrm{N}$ at $4 \mathrm{~h}$ postinoculation; D, I, and $\mathrm{O}$ at $24 \mathrm{~h}$ postinoculation; $\mathrm{E}, \mathrm{J}$, and $\mathrm{P}$ at $48 \mathrm{~h}$ postinoculation; F, K, and Q at $72 \mathrm{~h}$ postinoculation. In (b), lanes $\mathrm{B}, \mathrm{G}$, and $\mathrm{M}$, correspond to RT-PCR products from RNA obtained at $0 \mathrm{~h}$ postwounding; lanes $\mathrm{C}, \mathrm{H}$, and $\mathrm{N}$ at $6 \mathrm{~h}$ post-wounding; lanes $\mathrm{D}, \mathrm{I}$, and $\mathrm{O}$ at $12 \mathrm{~h}$ post-wounding; $\mathrm{E}, \mathrm{J}$, and $\mathrm{P}$ at $24 \mathrm{~h}$ post-wounding; and lanes $\mathrm{F}, \mathrm{K}$, and $\mathrm{Q}$ at $48 \mathrm{~h}$ post-wounding. pathogens and the plant defense regulator MeJA in both plant species. These results lay a foundation for future studies of the signaling processes involved in the induction of this plant peroxidase isogene promoter by fungal and Oomycete pathogens.

\section{RESULTS}

\section{Fungal infection and wounding induce transcripts of both Shpx6 isogenes in S. humilis.}

To distinguish the expression of the two isogenes, Shpx6a and Shpx6b, RT-PCR on total RNA isolated from young leaves of $S$. humilis was carried out following either inoculation with C. gloeosporioides (Fig. 1A) or wounding (Fig. 1B). Oligonucleotide primers were designed to the $5^{\prime}$ untranslated region of the mRNAs to specifically differentiate transcripts of these two peroxidase isogenes. The primers specific to Shpx6b were known to be positioned either side of an intron (Curtis et al. 1995) so that contaminating genomic DNA, if present, could be detected. In infection experiments, a 350-bp DNA fragment was strongly amplified from cDNA of transcripts corresponding to both the Shpx6a sequence and the Shpx6b sequence within $4 \mathrm{~h}$ after inoculation and both transcripts continued to show elevated expression $48 \mathrm{~h}$ postinoculation (Fig. 1A). Only a small amount of RT-PCR product was detected at time 0 in these infection experiments (Fig. 1A) and no increases in the transcripts of both Shpx6 genes were detected in mock-inoculated controls through the time course (data not shown; Harrison et al. 1995). In wounding experiments, the DNA fragment of approximately $350 \mathrm{bp}$, which corresponded to a Shpx6a transcript, was strongly amplified from RNA sampled at $6 \mathrm{~h}$ after wounding. The Shpx6a transcript was readily detected up to $24 \mathrm{~h}$ after wounding. A DNA fragment of similar size which corresponded to the Shpx6b transcript was also induced at $6 \mathrm{~h}$ after wounding, but continued to show expression for up to $48 \mathrm{~h}$ after wounding (Fig. 1B). No detectable RT-PCR fragment was amplified from RNA of untreated leaves using identical amplification conditions.

The nucleotide sequence of the 350-bp RT-PCR amplification products corresponding to Shpx6a and Shpx6b transcripts

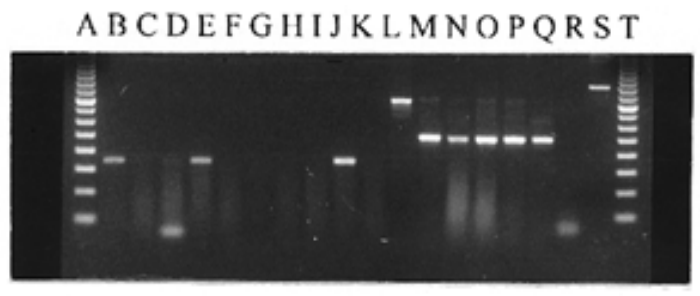

Fig. 2. RT-PCR analysis showing the expression of mRNAs corresponding to Shpx6a and Shpx6b in young leaves of Stylosanthes humilis $24 \mathrm{~h}$ after treatments with defense regulators. Lanes A and T contained the 100-bp marker ladder; lanes B to F correspond to RT-PCR products derived from transcripts of Shpx6a; lanes G to K correspond to RT-PCR products derived from transcripts of Shpx6b. Lane $\mathrm{L}$ corresponds to PCR products obtained from genomic DNA using primers for Shpx6b; lanes M to Q correspond to RT-PCR products derived from transcripts of CAD; lane $\mathrm{R}$ is a $\mathrm{H}_{2} \mathrm{O}$ control, and $\mathrm{S}$ corresponds to $\mathrm{PCR}$ products from genomic DNA using the CAD-specific primers. In (a) lanes $\mathrm{B}, \mathrm{G}$, and $\mathrm{M}$ correspond to RT-PCR products from RNA of leaves following INA treatment; $\mathrm{C}, \mathrm{H}$, and $\mathrm{N}$ to those following SA treatment; $\mathrm{D}, \mathrm{I}$, and $\mathrm{O}$ to ABA treatment; E, J, and P to MeJA treatment; and, F, K, and Q to control treatments. 
in both infection and wounding experiments were determined. The nucleotide sequences of these amplification products matched those predicted from the Shpx6a and Shpx6b isogenes, thus confirming the specificity of the RT-PCR analysis. A DNA fragment of approximately 800 nucleotides was amplified with the Shpx6b primers using purified genomic DNA of $S$. humilis as a template for PCR. This genomic amplification product was not detected in RT-PCR products derived from RNA preparations where only the predicted 350-bp product was obtained. This demonstrates that there was little or no contamination by genomic DNA in the RNA samples analyzed. Further control experiments to test the competence of all RNA samples for RTPCR were undertaken. Primers specific to a cinnamyl alcohol dehydrogenase (CAD) homologue (GSDB accession no. L36456), which is constitutively expressed in young leaves of $S$. humilis were used (Fig.1A and B). The primers were again positioned either side of an intron in the CAD gene. A DNA fragment corresponding to the CAD transcript of approximately 550 bp was generated in equal amounts from all RNA samples of control, wounded, and inoculated leaves. This verifies that none of the RNA samples used were degraded and all were competent for RT-PCR analysis. A DNA fragment of approximately $1 \mathrm{kbp}$ was amplified from genomic DNA with the CAD primers, confirming that the 550-bp fragment detected in the other lanes was derived from RNA. In summary, the RT-PCR analysis indicates that transcripts of both Shpx6 isogenes were induced in response to fungal infection and wounding in S. humilis.

\section{Methyl jasmonate induces transcripts of both Shpx6 isogenes in S. humilis.}

Plants of $S$. humilis were treated with the endogenous plant defense regulators: $\mathrm{SA}, \mathrm{ABA}$, and MeJA and also with the synthetic defense regulator 2,6 dichloroisonicotinic acid

\footnotetext{
-511 TAGGATTTGT GGGGTGGGGA GCATGgATTG CCATrTTTGA CAATGAGAgA

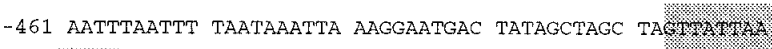

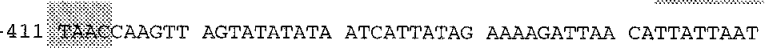
-361 TCATTGCTTC CACAAGAATG TTAGAGTTCA AGAGAAAAAC AAACAAAAGG -311 AGTTTCAAAA TAAATAAATA AaTAATAATA AaCAGCAAAT AATTAAGTGT

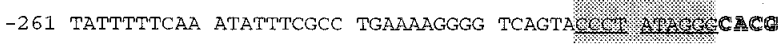

Fig. 3. The nucleotide sequence of the Shpx6b gene promoter. The transcriptional start site (arrowed) was determined by the direct sequencing of 5' RACE products. Putative CAAT and TATA boxes are underlined. A G-box (outlined font) and the two palindromic sequences (shaded), including a putative MJ box (shaded and underlined) are indicated. The putative Shpx6b translational start is boxed and the upstream ATG is boxed and underlined. The single nucleotide which was mutated to prevent initiation at this upstream ATG in the promoter-reporter construct pMC7 is shown in bold. The nucleotide positions are numbered from the transcriptional start. This sequence can be accessed in GSDB Accession \# L37790.
(INA) which is known to influence defense gene transcription (Uknes et al. 1992; Durner and Klessig 1995). Total peroxidase enzyme activity per unit protein of crude leaf homogenates was measured using guaiacol as a substrate (Harrison et al. 1995) at $24 \mathrm{~h}$ after treatment. Total peroxidase activity was increased two- to threefold after chemical treatments when compared with control plants (A. P. Stines, M. D. Curtis, E. A. B. Aitken, J. M. Manners, unpublished results). Total RNA samples were isolated from these plants $24 \mathrm{~h}$ after treatment and the expression of the two isogenes Shpx6a and Shpx6b was assayed using RT-PCR as described above (Fig. 2). A DNA fragment of approximately $350 \mathrm{bp}$ corresponding to a Shpx6b transcript was detected at $24 \mathrm{~h}$ after treatment with MeJA, while a similar-sized DNA fragment corresponding to a Shpx6a transcript was expressed after treatment with MeJA and INA. No expression of either transcript was detected in untreated control leaves. Again RT-PCR using primers specific to a CAD gene from $S$. humilis cv. Paterson was used as a control for the competence of RNA samples for RT-PCR analysis (Fig. 2). A RT-PCR product of approximately $550 \mathrm{bp}$ corresponding to the CAD transcript was detected in all RNA samples from treated and untreated leaves. RT-PCR products were sequenced directly and the specific isogene origin of each DNA fragment was verified. Amplification products were of the size predicted for RNA templates and the larger genomic amplification products were not detected, indicating that the RT-PCR products were derived from RNA. In summary, the RT-PCR analysis indicates that transcripts of both Shpx6 isogenes were induced in response to MeJA treatment.

\section{Sequence analysis of the upstream promoter region of the Shpx6b isogene.}

A genomic clone of the Shpx6b gene was obtained previously from a genomic library of $S$. humilis prepared in the vector EMBL3 (Curtis et al. 1995). The nucleotide sequence of intron, exon, and immediate flanking sequences of the Shpx6b gene have been reported previously (Curtis et al. 1995). Here we report $513 \mathrm{bp}$ of the nucleotide sequence upstream of the translational start (Fig. 3). A 5' rapid amplification of cDNA ends (RACE) procedure with total RNA from leaves of $S$. humilis following inoculation with $C$. gloeosporioides was used to identify the transcriptional start of the Shpx6b isogene using a primer specific to the Shpx6b transcript. The DNA sequence (350 bp) of the amplified 5' RACE product corresponded exactly to the sequence predicted from the genomic clone of the Shpx6b gene confirming the specificity of the RACE primer for this particular isogene. Sequence analysis of the RACE product indicated that the $5^{\prime}$ terminus of the Shpx6b transcript was located $80 \mathrm{bp}$ upstream of the translation initiation site predicted for the Shpx6b peroxidase and this position was therefore assigned as the transcription initiation site (Fig. 3). The identified transcription inititation site was typical of a class II gene with $\mathrm{C}$ and A nucleotides located at positions -1 and +1 , respectively (Wies and Reinberg 1992; Aso et al. 1994). A TATA box was located -25 nucleotides from the transcription initiation site, a CAAT box at -165 nucleotides and a G-Box motif CACGTG, (Williams et al. 1992) at -206 nucleotides. Several palindromic sequences were identified in the $5^{\prime}$ regulatory sequence of the gene. These may represent cis-elements involved in the regulation of transcription of the gene. Of particular interest were a five nucleotide inverted repeat (CCCTATAGGG) directly up- 

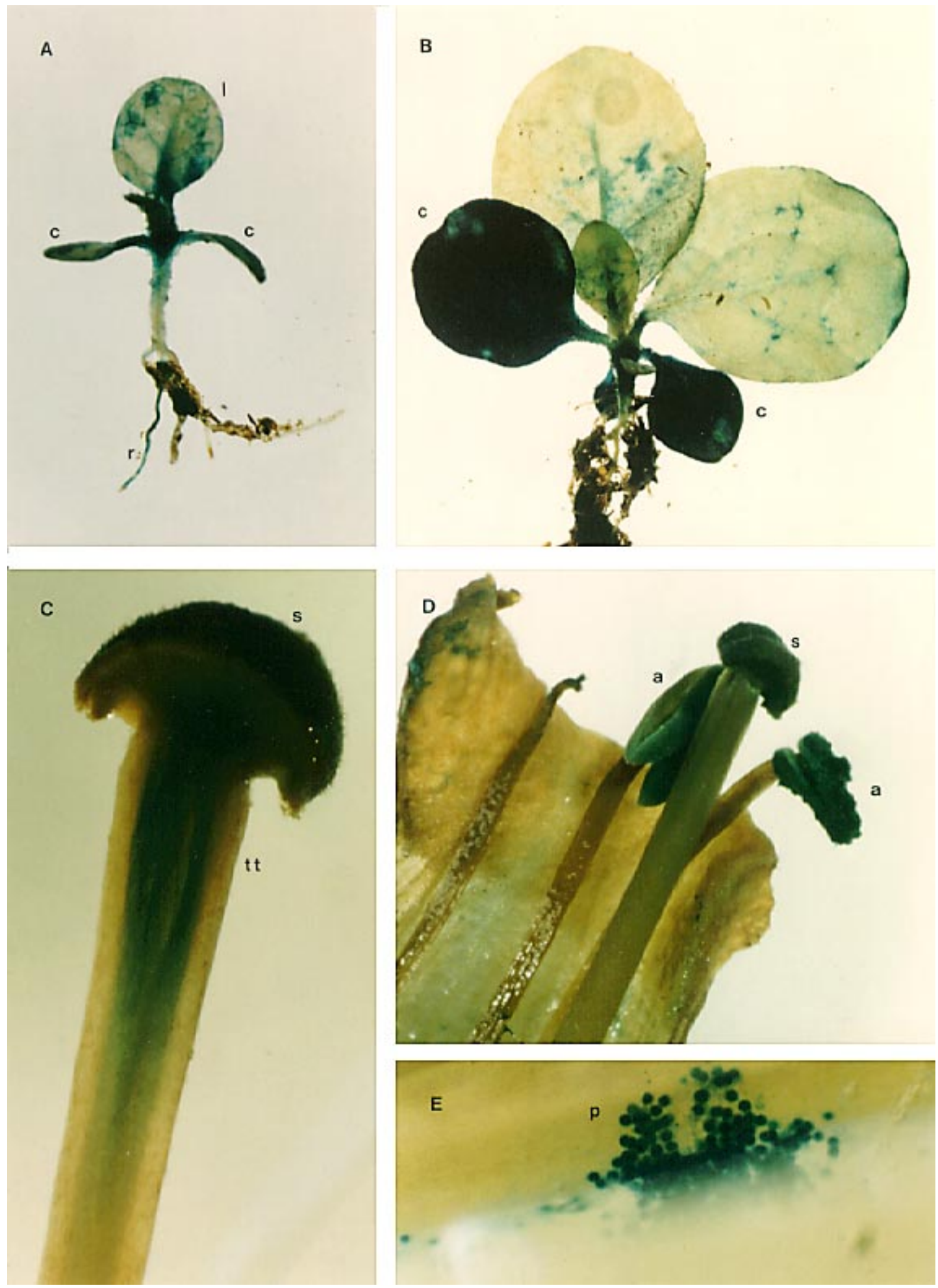

Fig. 4. (A-E). Representative examples of Shpx6b promoter-driven GUS expression during developmental stages of $\mathrm{T}_{1}$ transgenic plant pMC7 lines. A, A 16 day-old seedling showing GUS staining in roots ( $\mathrm{r}$ ), young leaves and cotyledonary node; B, A 21-day-old seedling showing strong GUS expression in the cotyledon (c) and lower amounts in leaves; C, A stigma (s) and style cut longitudinally showing blue staining in the transmitting tissue (tt); D, anthers (a) and; E, pollen grains (p). 
stream and contiguous with the G-Box at -211 nucleotides and a six nucleotide inverted repeat (GTTATTAAT AAC) at position -403 . An additional ATG sequence at nucleotide position +73 was identified in the transcribed nucleotide sequence upstream of the translation initiation site $(+80$ position) predicted for the deduced peroxidase protein of the Shpx6b gene. Translation from this upstream ATG would produce a 9-amino acid peptide. The sequence surrounding the ATG initiating the Shpx6b protein, however, was significantly more homologous to consensus plant translation initiation sequences (Joshi 1987).

\section{Shpx6b promoter-reporter gene fusions.}

The coding region of the uidA gene (Jefferson et al. 1987) of Escherichia coli encoding $\beta$-glucuronidase (GUS) was used as a reporter to characterize expression conferred by the Shpx6b promoter region in transgenic plants. Two recombinant plasmids containing Shpx6b chimeric genes were constructed in the binary vector pBI101.3 and these were called pMC6 and pMC7. In both pMC6 and pMC7, 594 bp of the upstream untranslated sequences of the Shpx6b gene (see Fig. 3) were ligated to the uidA cistron of $\mathrm{pBI} 101.3$ forming an in-frame translational fusion with the translation initiation AUG codon (position +80 ) of the Shpx6b peroxidase. The plasmid pMC7 contains a singlesite specific nucleotide change from a $\mathrm{T}$ to a $\mathrm{G}$ at position +74 which would prevent any initiation of translation at the upstream AUG codon which may reduce reporter gene expression. The plasmids were transferred to Agrobacterium tumefaciens AGL1 (Lazo et al. 1991) and used to transform Nicotiana tabacum cv. Xanthi. Preliminary histochemical staining for GUS in several primary $\left(\mathrm{T}_{0}\right)$ transgenic lines led to the selection of seven pMC7 lines and two pMC6 lines which showed detectable expression of GUS. These lines were taken to flower and $\mathrm{T}_{1}$ seed collected for further study.

\section{Expression from the Shpx6b promoter during plant development.}

Germinating $\mathrm{T}_{1}$ seedlings of all selected transgenic $N$. tabacum cv. Xanthi lines transformed with pMC6 and pMC7 showed some reporter gene expression in the developing cotyledon. Representative examples of the developmental

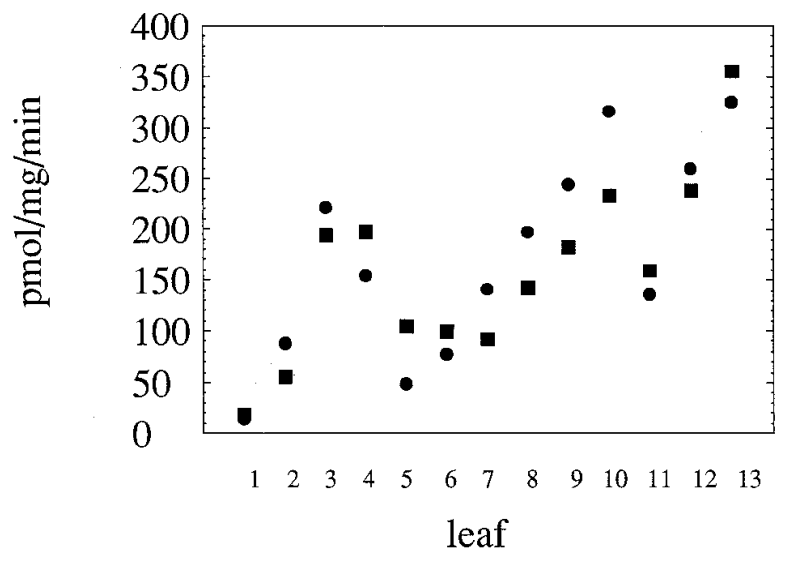

Fig. 5. GUS activity in the leaves from two independent mature $T_{2}$ transgenic tobacco plants of line pMC7/5. Leaves are numbered from the base of the plant so that leaf 1 is the oldest leaf. stages of Shpx6b promoter-GUS expression are shown in Figure 4. Sixteen-day-old plants showed strong GUS staining in the roots, cotyledons, leaf nodes, and petioles with patchy expression in the young leaves (Fig. 4A). Twenty-one-day-old plants showed very strong GUS staining in cotyledons, and leaf nodes, with mild staining in young leaves restricted to the vascular tissue or the margin of more fully expanded leaves (Fig. 4B). The detection of GUS activity in young leaf tissue and roots in tobacco is consistent with the analysis of the expression of the Shpx6 isogenes in S. humilis where Shpx6 mRNAs were detected in young leaves and roots (Harrison et al. 1995). In the flowers of transgenic tobacco, GUS activity was observed in the stigma and transmitting tissue of the style (Fig. 4C-D), the anthers (Fig. 4D), and pollen grains (Fig. 4E). It has been suggested that GUS expression in pollen grains driven by a pathogenesis-related (PR) protein gene promoter (Uknes et al. 1993) may be artifactual and influenced by regulatory features of the uidA coding sequences. This is probably not the case for the Shpx6b promoter-GUS fusion because expression of a gene product that causes cell death from the Shpx6b promoter in transgenic tobacco plants resulted in very low viability in pollen grains (K. Kazan, M. Curtis, and J. Manners, unpublished).

Using the fluorogenic substrate 4-methyl umbelliferyl glucuronide (MUG) the expression of GUS was quantified in leaves sampled from each node of two independent mature $T_{2}$ plants of one transgenic line derived using pMC7 (Fig. 5). In these plants the transgene was most strongly expressed in the youngest leaves. Histochemical staining revealed that this expression is mainly limited to the vascular tissue of the leaves (data not shown). This profile of reporter gene expression in adult plants demonstrated the importance of sampling leaves at the same developmental stage in control and treated plants in the studies of gene induction described below. All subsequent gene induction studies with mature plants used the first fully expanded leaves (nodes 5 to 7, Fig. 5).

\section{Induction of the Shpx6b promoter by pathogens and wounding.}

Leaf strips from adult $\mathrm{T}_{0}$ transgenic tobacco plants were inoculated with mycelial plugs of the Oomycete pathogen Phytophthora parasitica var. nicotianae or mock inoculated with agar blocks and histochemically stained for GUS activity. The seven independent pMC7 transformants and the two pMC6 transformants were examined and similar staining patterns were observed in all lines, although the intensity of gene expression showed some variation between transgenic lines. The strongest pathogen-induced GUS staining observed in $\mathrm{T}_{0}$ transgenic tobacco was in the plant line $\mathrm{pMC} 7 / 5$ and $\mathrm{T}_{1}$ plants of this line were used for more detailed analysis. Figure 6 (panels A-C) shows representative examples of the pattern of expression of the reporter gene activity in $T_{1}$ plants of this transgenic line. In control experiments, GUS activity was localized to 1 to $2 \mathrm{~mm}$ around the wound site used for mockinoculation and was similarly restricted to the cut edges of the leaf strips. In infection experiments, GUS activity was again localized to 1 to $2 \mathrm{~mm}$ at the cut leaf edges but extensive GUS activity was observed up to 10 to $20 \mathrm{~mm}$ from the edge of the necrotic lesion which developed from the site of infection. Sections taken through leaves of line pMC7/5, infected by $P$. parasitica var. nicotianae, showed that GUS activity was 
present in all leaf cell types (data not shown). The leaves were counterstained with Keane's solution (Keane et al. 1988), to specifically stain the fungal hyphae. This revealed that GUS activity was present in plant cells up to $1 \mathrm{~cm}$ distant from the advancing hyphal front (Fig. 6D).

Leaves of adult $\mathrm{T}_{1}$ transgenic plants of the line pMC7/5 were also inoculated with conidia of the Deuteromycete phytopathogen Cercospora nicotianae which causes 'frog eye' disease on tobacco leaves. Histochemical staining revealed strong and widespread GUS activity in inoculated leaves when compared to mock-inoculated controls (Fig. 6E). The GUS activity appeared to surround the expanding lesions on these leaves.

\section{Induction of the Shpx6b promoter by methyl jasmonate.}

Adult $\mathrm{T}_{2}$ transgenic tobacco plants of line $\mathrm{pMC} 7 / 5$ were treated with the plant defense regulators MeJA, ABA, $\mathrm{H}_{2} \mathrm{O}_{2}$, and SA. Total GUS activity from crude leaf homogenates extracted from plants treated with these plant defense regulators was measured at $24 \mathrm{~h}$ after treatment (Fig. 7). A highly significant 2.5-fold increase in GUS activity was detected after treatment with $25 \mu \mathrm{M}$ MeJA when compared to controls. No significant differences were observed between the GUS activity of plants treated with $100 \mu \mathrm{M} \mathrm{ABA}, 1 \mathrm{M} \mathrm{H}_{2} \mathrm{O}_{2}, 5 \mathrm{mM} \mathrm{SA}$ and that of control treatments. Northern hybridization analysis of total RNA from the same plant line showed that the abundance of PR1a mRNA was strongly increased $24 \mathrm{~h}$ after treatment with only $2 \mathrm{mM}$ SA (results not shown). However, treatment with up to $10 \mathrm{mM}$ SA did not cause any significant increase in GUS activity (results not shown).

The results obtained with mature transgenic plants of the pMC7/5 line suggest that the Shpx6b promoter can be induced by MeJA. To test whether the induction by MeJA was a general characteristic of the promoter, the effect of MeJA on GUS activity in all the selected transgenic lines was investigated. To conveniently assay a large number of plant lines with sufficient replication, $\mathrm{T}_{1}$ seed was germinated on modified $\mathrm{MS}$ media containing either 2.5 or $5 \mu \mathrm{M}$ MeJA and compared to control seedlings grown on modified MS media alone. Transgenic tobacco containing the T-DNA of the binary vector pBI121, which contains a 35S-uidA reporter gene, was treated in the same way as the other transgenic plant lines as a control. A summary of the GUS activity in these experiments is shown in Figure 8. After germination for 8 days on media containing MeJA, four out of five of the pMC7 plant lines showed significant increases in GUS activity on media containing $2.5 \mu \mathrm{M}$ MeJA and all five of these lines showed increased GUS activity on media containing $5 \mu \mathrm{M}$ MeJA (Fig. 8). Line pMC7/5 showed less induction of GUS by MeJA at the seedling stage (Fig. 8) than was observed in leaves of mature plants (Fig. 7), suggesting that the response may be also influenced by plant development. Line 2 of the pMC7 transgenic plants studied showed the greatest induction in response to MeJA treatment. This line had a 5.5-fold increase in GUS activity following exposure to $5 \mu \mathrm{M}$ MeJA. The mean induction for all 5 pMC7 lines was 3.6-fold that of control plants. In contrast, there was no significant difference in GUS activity between control and MeJA treated 35S-uidA transgenic plants. In similar experiments using $\mathrm{T}_{1}$ plantlets from the two pMC6 lines, treatment with MeJA resulted in increases in GUS activity over controls similar to those ob- served for the pMC7 lines. However, the levels of GUS activity detected in both control and treated plantlets of the pMC6 lines were approximately 10 -fold lower than those of the pMC7 lines (data not shown). To test the response of the Shpx6b promoter to jasmonates other than methyl jasmonate, seedlings of $\mathrm{T}_{1}$ plants of line $\mathrm{pMC} 7 / 5$ were germinated on 5 , 25 , and $50 \mu \mathrm{M}$ jasmonic acid. The mean GUS activity in these seedlings was induced 1.5-, 2-, and 2.5-fold, respectively, over controls grown in the absence of jasmonic acid (data not shown). These results confirm the sensitivity of the Shpx6b promoter to jasmonates in the pMC7/5 line.

Salicylic acid has been shown to be intimately involved with the defense response in higher plants and induces PR protein gene expression (Ryals et al. 1994). Results obtained in earlier experiments with mature plants of the pMC7/5 line suggest that the Shpx6b promoter was not induced by SA treatments that stimulated PR1a expression. To test whether this was a general characteristic of the promoter, the effect of SA on GUS activity in all the selected transgenic lines was investigated using the seedling assay described above. Millimolar concentrations of SA were inhibitory to germination in this assay. Concentrations of SA up to $50 \mu \mathrm{M}$ appeared to have no effect on GUS activity in germinating seedlings. However, after germination on media containing higher but apparently non-toxic concentrations of SA (200 to $500 \mu \mathrm{M})$ there was significant induction of GUS. For example, three out of five of the pMC7 plant lines, including the pMC7/5 line, showed significant increases in GUS activity on media containing $200 \mu \mathrm{M}$ SA and four out of five lines showed increased GUS activity on media containing $500 \mu \mathrm{M}$ SA (Fig. 9). In general, the induction of GUS activity by SA was much lower than that observed in MeJA treatments (Fig. 8). The mean induction for all five pMC7 lines was only 1.4-fold that of control plants. In similar experiments using $\mathrm{T}_{1}$ transgenic plantlets from the two pMC6 lines, treatment with 200 and $500 \mu \mathrm{M}$ SA also resulted in one- to twofold increases in GUS activity, relative to controls. However, the overall levels of GUS activity detected in both control and treated plantlets of the pMC6 lines were again approximately 10-fold lower than those of the pMC7 lines (data not shown). Again, there was no significant difference in GUS activity between control and SA treated 35S-uidA transgenic plants (Fig. 9).

The $\mathrm{T}_{2}$ seed from a pMC7/5 plant was germinated on modified MS media containing both $2.5 \mu \mathrm{M}$ MeJA and $200 \mu \mathrm{M}$ SA or both $5 \mu \mathrm{M}$ MeJA and $500 \mu \mathrm{M}$ SA to determine if these gene regulators have synergistic effects on the expression of the Shpx6b promoter. After germination for 8 days on media containing MeJA and SA the pMC7/5 plantlets showed no significant increases in GUS activity when compared to plantlets grown on media containing MeJA alone, but did show an increase in GUS activity when compared to plantlets grown on media containing only SA (data not shown). All treatments showed significant transgene induction when compared to the control plants.

\section{DISCUSSION}

We have characterized the expression of the Shpx6b peroxidase gene from $S$. humilis. The expression of the Shpx6b gene was studied in $S$. humilis using isogene-specific RT-PCR techniques and a Shpx6b promoter region further character- 

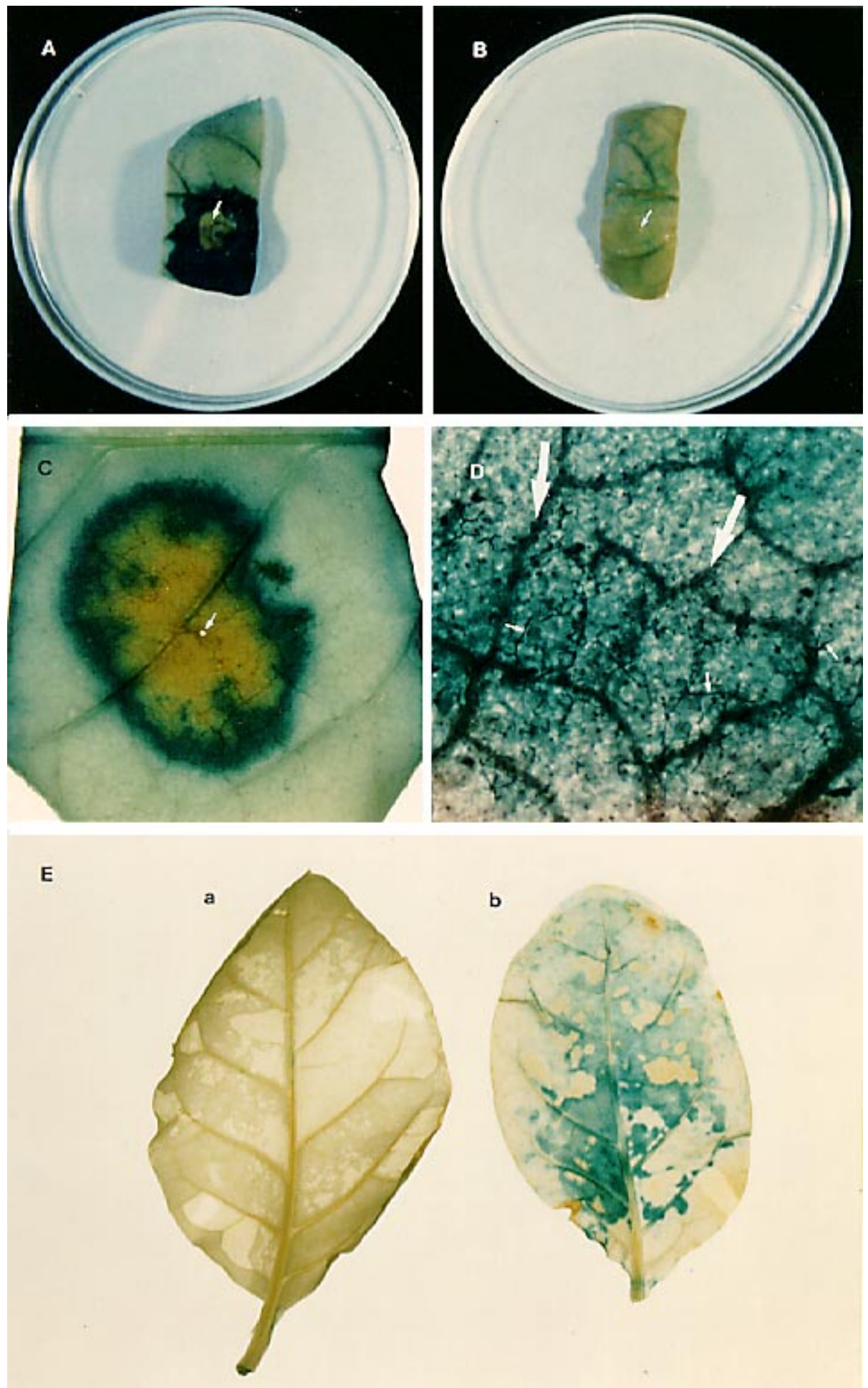

Fig. 6 (A-C). Representative examples of the pattern of GUS expression in leaves of $T_{1}$ transgenic tobacco plants (line pMC7/5) after inoculation with either the Oomycete Phytophthora parasitica var. nicotianae (A-D) or the fungus Cercospora nicotianae (E). A, Leaf segment at $72 \mathrm{~h}$ following inoculation with P. parasitica var. nicotianae; B, after mock inoculation; C, a second example after $48 \mathrm{~h}$ of infection at $10 \times$ magnification showing the expression of GUS along the cut edges of the leaf strip but more extensively distributed around the lesion (the white arrows in A-C indicate the wound site used in the inoculation procedure); D, shows a further example of an infection site histochemically stained for GUS and counter stained with Keane's solution (100x magnification). The leaf was viewed from the lower surface and the brown region at the bottom of the frame represents the edge of the necrotic lesion. The large white arrows show the limit of hyphal growth and the smaller white arrows show individual hyphae in the leaf tissue; $\mathbf{E}$, shows leaves from adult transgenic plants of the line pMC7/5 histochemically stained for GUS at 7 days after either mock inoculation (a) or inoculation with conidia from the fungal plant pathogen C. nicotianae (b). 
ized using uidA reporter gene fusions in transgenic tobacco. In both plant species, gene expression from the Shpx6b promoter appeared to be induced by microbial pathogens, by wounding, and by exogenous application of the plant defense regulator MeJA. Although the roles of peroxidases in plant-pathogen interactions have been studied extensively, to our knowledge, this is the first report of a cloned peroxidase gene that is induced by microbial pathogens and methyl jasmonate.

The Shpx6b gene promoter was induced by wounding and fungal pathogen attack in S. humilis and by wounding and both fungal and Oomycete pathogen attack in tobacco. However, the regulation of pathogen-induced expression of this gene appears to differ from that of wounding. Firstly, in the interaction of $C$. gloeosporioides with $S$. humilis spores germinate within 3 to $6 \mathrm{~h}$ after inoculation and then differentiate into an appressorium which subsequently melanizes and forms a penetration peg at 6 to $12 \mathrm{~h}$ postinoculation (Irwin et al. 1984; Ogle et al. 1990). Interestingly, spores of C. gloeosporioides also secrete an adhesion matrix prior to germination (Jones et al. 1995). Therefore the Shpx6b gene is induced prior to fungal penetration and several hours before host cell death is detected in this interaction (Harrison et al. 1995). It would appear that the Shpx6 promoter must respond to molecular signals released from either the pathogen on the leaf surface or from living host cells rather than to signals from dead or disrupted host cells as would be the case in a wound response. Secondly, in transgenic tobacco plants, the GUS expression observed around pathogen infection sites was much more extensive than that observed around wound sites and

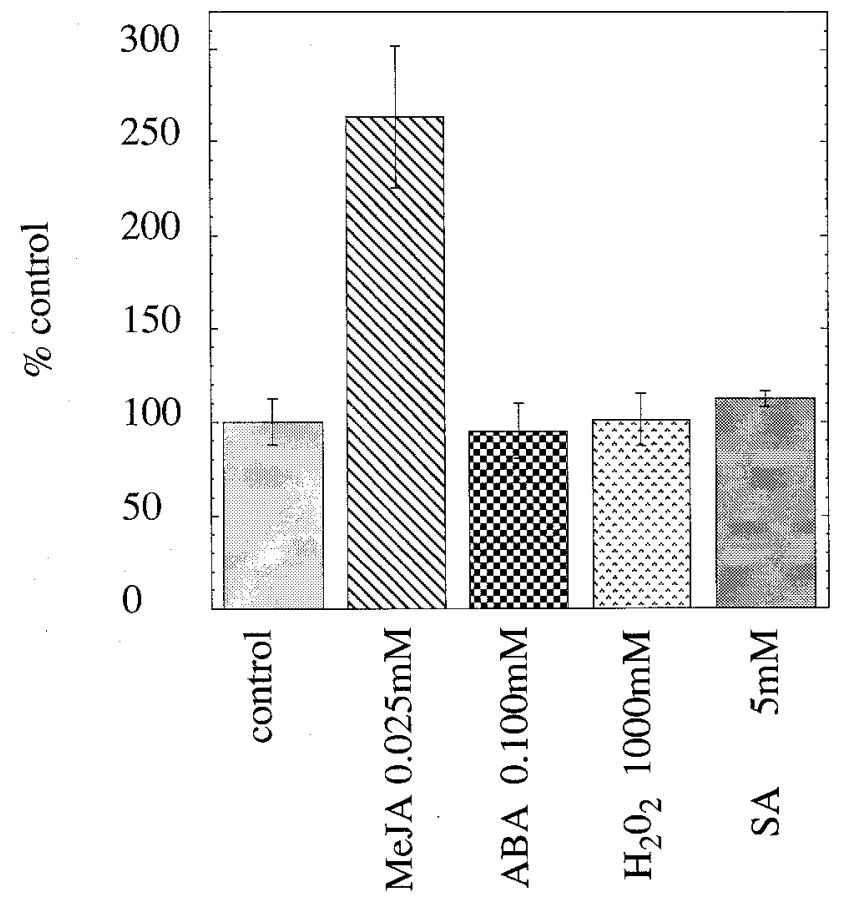

Fig. 7. GUS activity in adult $T_{2}$ transgenic tobacco cv. Xanthi plants of line pMC7/5 treated with with $25 \mu \mathrm{M}$ methyl jasmonate, $100 \mu \mathrm{M}$ abscisic acid, $1 \mathrm{M} \mathrm{H}_{2} \mathrm{O}_{2}, 5 \mathrm{mM}$ salicylic acid, and mock-treated control plants. The data are means obtained from three different leaves (leaves 5-7) from three independent plants $24 \mathrm{~h}$ after treatments expressed as percentage of control values $( \pm$ standard error normalized as a proportion of the mean). The mean value of GUS activity for control plants was $118.75 \mathrm{pmol} \mathrm{MU} \mathrm{mg}$ protein ${ }^{-1} \mathrm{~min}^{-1}$. was remote from invading pathogen hyphae. These observations suggest that pathogens either produce or promote the release of diffusable signals to which the Shpx6b gene promoter is responsive. We have tested the plant signal molecules MeJA, SA, ABA, and $\mathrm{H}_{2} \mathrm{O}_{2}$ for their ability to induce Shpx6b gene expression, but we have not made an exhaustive study, and other signals such as ethylene and auxin may also have a role in signaling gene induction. Nonetheless, present results implicate MeJA as a potential signal molecule for the induction of the Shpx6b gene.

Methyljasmonate is a signal molecule produced in plants in response to wounding (Creelman et al. 1992). Circumstantial evidence exists linking MeJA to the host defense response to microbial pathogens (Baron and Zambryski 1995). MeJA is a methyl ester of JA (Meyer et al. 1984) which is synthesized in plants from linolenic acid. It has been proposed that MeJA and JA might function as secondary messengers in tomato (Farmer and Ryan 1992). In this model, release of the peptide systemin as a result of tissue injury may lead to activation of a lipase in the plasma membrane resulting in the production of linolenic acid which can then be rapidly converted to JA. However, JA is not only found in plants, but has also been reported in fungi

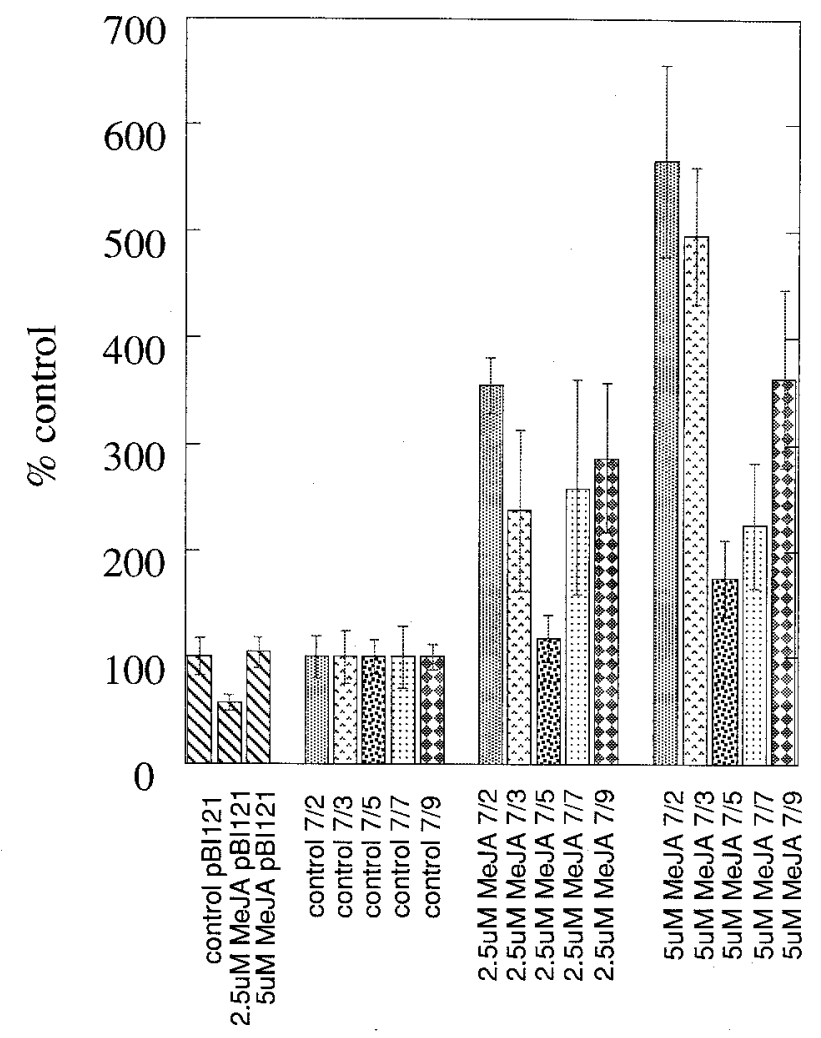

Fig. 8. The Shpx6b promoter is MeJA responsive in multiple transgenic lines. Independent $\mathrm{T}_{1}$ seed of transgenic tobacco pMC7 lines 2, 3, 5, 7 and 9 were germinated on modified MS media containing either $2.5 \mu \mathrm{M}$ or 5 $\mu \mathrm{M}$ MeJA and compared to controls where seedlings of the same lines were grown on modified MS media with no MeJA. Date for transgenic tobacco containing the T-DNA of the binary vector pBI121 treated in the same way is also shown. Data are mean values of GUS activity obtained from independent assays of five independent plantlets after 8 days growth expressed as percentage of control values \pm standard error. Mean values for the GUS activity for control plants in assays of the pBI121, pMC7/2, $\mathrm{pMC} 7 / 3, \mathrm{pMC} 7 / 5$, pMC7/7, and pMC7/9 lines were 570.47, 17.90, 6.32, $68.04,11.53$ and $21.54 \mathrm{pmol} \mathrm{MU} \mathrm{mg} \mathrm{protein}{ }^{-1} \mathrm{~min}^{-1}$, respectively. 
(Sembdner and Parthier 1993). Although the Shpx6b gene has been shown to be induced by both pathogens and MeJA our results do not directly demonstrate a role for MeJA in pathogen-induced gene expression. A notable feature of the Shpx6b gene is its rapid induction during infection, even preceding fungal penetration (Fig. 1A, Harrison et al. 1995). If MeJA does have a role in this rapid host response it could be either as a second messenger produced in the plant or perhaps as an elicitor released by the germinating spores. These two possibilities require further investigation.

The Shpx6b promoter contains several palindromic sequences which may represent cis-elements involved in the regulation of this peroxidase isogene by pathogens and methyl jasmonate. One of these sequences is the so-called G-box (CACGTG) motif (Schindler et al. 1992), a cis-element which has been shown to play a major role in the induction of many stress-induced genes. A G-box has been shown to be important in the woundinduced expression of a horseradish peroxidase gene (Kawaoka et al. 1994). In the promoters of the soybean vegetative storage protein (vspB) gene (Mason et al. 1993) and the potato proteinase inhibitor II gene (Farmer and Ryan 1990; Kim et al. 1992) the G-box is thought to be involved in MeJA responsiveness. Promoters containing the $\mathrm{G}$ box do not necessarily respond to all of the stresses and signals in which this cis-element has been implicated (Hindmann et al. 1992; Reinbothe et al. 1992). It has been suggested that the nucleotide sequence flanking the core

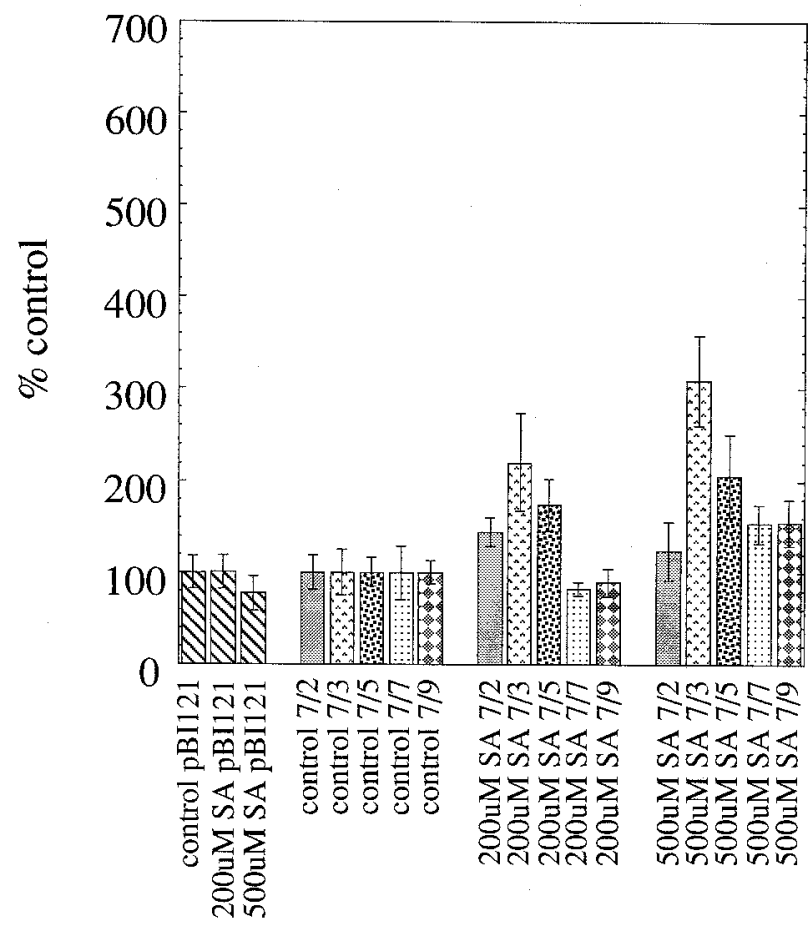

Fig. 9. The GUS activity in independent $T_{1}$ seed lines of transgenic tobacco pMC7 lines 2, 3, 5, 7, and 9 grown on modified MS media containing either 200 or $500 \mu \mathrm{M} \mathrm{SA}$ and compared to that of control seedlings grown on modified MS media with no SA. The effect of SA on GUS activity of a transgenic tobacco line containing the T-DNA of the binary vector pBI121 is also shown. The data are means obtained from five independent plantlets after 8 days growth expressed as percentage of control values ( \pm standard error as a proportion of the mean). The mean values for the GUS activity for control plants were as described in Figure 8 .
G-box motif may be involved in providing the specificity determinants for the G-box binding protein (Williams et al. 1992) together with other cis-elements upstream and downstream of the G-box. One such cis-element may be the so-called C-rich domain which has previously been found upstream of the wound-inducible genes phenylalanine ammonia-lyase and chalcone synthase (Staiger et al. 1989; Schindler et al. 1992). More recently, this $\mathrm{C}$-rich domain has been implicated as a potential MeJA responsive domain (MJ-box) in the soybean $v s p B$ gene promoter (Mason et al. 1993). A similar domain is found upstream of the G-box in the Shpx6b promoter. This putative MJbox in the Shpx6b promoter is a 10-nucleotide palindrome (CCCTATAGGG) that is contiguous with the G-box. An alignment with a domain upstream of a G-box, implicated in MeJA responsiveness of the $v s p B$ vegetative storage protein gene promoter of soybean identifies the sequence CCCTAGAACC (Mason et al. 1993), which shows 6-nucleotide identity and an additional single purine match to the putative MJ-box in the Shpx6b promoter. A detailed dissection of this promoter is now warranted to identify key cis-elements involved in MeJA and pathogen induction.

In $S$. humilis transcripts of the Shpx6 isogenes were not induced by SA and the Shpx6b promoter was not SA responsive in mature transgenic tobacco (Figs. 2 and 8). In agreement with previous work (Uknes et al. 1993), exogenous application of SA strongly induced the endogenous PR1a mRNA in these transgenic tobacco plants. This indicates that the Shpx6b gene, and probably also the Shpx6a gene, are unlikely to be regulated by a SA signaling pathway believed to be involved in PR1a induction. There are other examples of plant genes that are induced by fungal pathogens and methyl jasmonate but are nonresponsive to salicylic acid. These include the thionin and defensin genes of Arabidopsis thaliana (Epple et al. 1995; Penninckx et al. 1996). It has recently been proposed that signaling pathways independent of the salicylic acid pathway are activated both locally and systemically in plants following fungal challenge and that components of the jasmonate and ethylene signal transduction pathways may play roles in this pathway (Penninckx et al. 1996). In transgenic seedling experiments, plantlets exposed to SA showed slightly increased GUS activity. This level of induction of GUS activity was much lower than that observed in germinating plantlets exposed to MeJA, despite using concentrations of SA which were 500 times greater than that of MeJA. The apparent difference in the response to SA in adult plants and germinating seedlings may be due to differences in the regulation of the Shpx6b gene at different developmental stages of the plants or due to pleiotropic effects from extended exposure to near lethal concentrations of SA. A possible influence of development is indicated by the pattern of GUS activity in young transgenic tobacco plants which expressed GUS strongly in cotyledons. Combinations of defense regulators can synergistically induce some pathogenesis-related defense genes (Xu et al. 1994). However, our results suggest that no synergistic effects on the Shpx6b promoter are produced by combinations of MeJA with SA in the seedlings.

Both Shpx6a and Shpx6b peroxidase isogenes appeared to be expressed similarly in response to fungal infection, wounding, and MeJA treatment in S. humilis. Although these isogenes appear to be expressed coordinately during fungal attack and wounding, some differences in their signal pathways may exist. 
A Shpx6a RT-PCR product was amplified from total RNA extracted from $S$. humilis $24 \mathrm{~h}$ after treatment with the synthetic defense regulator INA, but this chemical did not induce a Shpx6b RT-PCR product. This highlights possible differences in the regulatory signals of these isogenes. INA induces the expression of the same set of systemic acquired resistance (SAR) genes as that induced by SA (Uknes et al. 1992) but more recently, it has been found that the accumulation of SA is not induced by INA (Vernooij et al. 1995). INA is, therefore, thought to induce the SAR signal transduction pathway at the same point or downstream of SA. The induction of the Shpx6a gene in $S$. humilis by INA, but not SA, provides further support that INA can act independently of SA.

In addition to transcriptional regulation, the Shpx6b gene may be regulated at the level of translation. The translation of mRNA is emerging as an important step in the specific regulation of eukaryotic genes (Geballe and Morris 1994). The presence of upstream open reading frames (uORFs) in the $5^{\prime}$ leader sequence can dramatically influence the translation of specific mRNA molecules (Morris et al. 1993). The nucleotide sequence of the Shpx6b promoter revealed an additional AUG sequence in the $5^{\prime}$ leader sequence upstream of the predicted translation initiation site of the Shpx6b peroxidase coding region. This uORF appears to reduce the translation of the uidA reporter gene 10 -fold in transgenic plants. The sequence surrounding the upstream AUG of Shpx6b has little homology to the consensus plant translation initiation sequence. This would cause the upstream AUG to be weakly recognized, allowing some translation from the legitimate AUG initiation codon in the Shpx6b gene. The expression of GUS activity from the pMC6 construct in transgenic plants directly demonstrates translation did occur from the downstream AUG codon. However, translation of GUS in plants transformed with the pMC6 construct which contained the uORF was substantially lower than that observed in transgenic plants containing the pMC7 construct where the upstream AUG had been modified. Therefore the upstream AUG codon does appear to reduce expression from the downstream peroxidase translation initiation codon. The uORF in the native gene promoter may act, therefore, as a further regulator moderating the expression of the downstream reading frame.

The induction of peroxidase is an early event in the interaction of $S$. humilis and $C$. gloeosporioides (Harrison et al. 1995). Peroxidase induction appears to occur in both compatible and incompatible interactions in this host-pathogen interaction. Our studies indicate that the Shpx6b gene encoding a putative peroxidase responds to infection by $C$. gloeosporioides in $S$. humilis and that the promoter of this gene responds to pathogen invasion in a heterologous transgenic tobacco plant system. These results suggest that this promoter may have biotechnological application for the expression of novel gene products at fungal infection sites in experiments aimed at engineering disease resistance in diverse plant species.

\section{MATERIALS AND METHODS}

\section{Plant material.}

Plants of $S$. humilis cv. Paterson and transgenic plants of $N$. tabacum cv. Xanthi were cultivated in a controlled environment with a $28^{\circ} \mathrm{C}$ light regime for $16 \mathrm{~h}$ and a $20^{\circ} \mathrm{C}$ night regime for $8 \mathrm{~h}$ at $70 \%$ relative humidity.

\section{Inoculation and wounding experiments.}

The pathogen Colletotrichum gloeosporioides biotype A, isolate SR24 was cultured on solid oatmeal agar and conidia collected were used to inoculate mature plants of $S$. humilis as described previously (Harrison et al. 1995). Young leaves of $S$. humilis were either inoculated with conidia of C. gloeosporioides or wounded as described previously (Harrison et al. 1995). Cercospora nicotianae was cultured on solid V8 medium supplemented with ground tobacco leaves under near$\mathrm{UV}$ light at $25^{\circ} \mathrm{C}$ to promote sporulation. Adult plants were inoculated using a modification of a method described by Zhu et al. (1994). Plants were sprayed with an inoculum suspen-

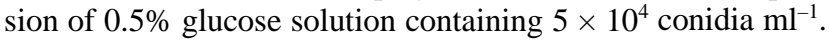
Control plants were mock inoculated with a $0.5 \%$ glucose solution. After 5 days in a dew chamber at $25^{\circ} \mathrm{C}$ plants were maintained at $25^{\circ} \mathrm{C}$ with a $16 \mathrm{~h}$-light $/ 8 \mathrm{~h}$-dark cycle until disease symptoms developed. Phytophthora parasitica var. nicotianae isolate 9201 was cultured on V8 medium (20\% V8 juice, $2 \%$ agar, and $0.2 \% \mathrm{CaCO}_{3}$ ) at $25^{\circ} \mathrm{C}$ for 5 days under continuous UV light. Leaf strip inoculations for tobacco with P. parasitica var. nicotianae were carried out using a modification of the method described by Robin and Guest (1994). For visualization of oomycete hyphae in transgenic tobacco previously histochemically stained for GUS activity, leaf segments were subsequently stained and cleared by the method of Keane et al. (1988). Segments were submerged for 2 days at room temperature in a solution containing Chlorazol Black E, ethanol, chloroform, lactic acid, phenol, and chloral hydrate. Destaining for 2 days in a solution of chloral hydrate resulted in blue-black staining of fungal cytoplasm with no loss of GUS reaction product.

\section{Chemical treatments.}

Mature plants were sprayed with a solution of $0.01 \% \mathrm{EtOH}$, $0.1 \%$ Triton $\mathrm{X}-100$ in water containing one of the following: 2, 5, or $10 \mathrm{mM} \mathrm{SA}$ (pH 6.5)(Sigma Chemicals Ltd.), $100 \mu \mathrm{M}$ ABA (pH 6.8), (Sigma), 20 ppm INA (pH 6.8) (Ciba-Geigy AG, Basel, Switzerland) formulated as a $25 \%$ active ingredient with a wettable powder carrier, $25 \mu \mathrm{M}$ MeJA (pH 6.8)(Sigma) or $0.1 \mathrm{M}, 0.3 \mathrm{M}$ or $1 \mathrm{M} \mathrm{H}_{2} \mathrm{O}_{2}(\mathrm{BDH})$. Control plants were treated with $0.01 \% \mathrm{EtOH}, 0.1 \%$ Triton $\mathrm{X}-100$ in $\mathrm{H}_{2} \mathrm{O}$. Seedlings were germinated on Murashige and Skoog (1962) (MS) salts without sucrose which contained $200 \mu \mathrm{g}$ $\mathrm{ml}^{-1}$ kanamycin (Sigma), and 2.5 or $5 \mu \mathrm{M} \mathrm{MeJA}, 200 \mu \mathrm{M}$, or $500 \mu \mathrm{M}$ SA or in combination.

\section{Plasmid construction.}

Digestion of DNA with restriction endonucleases, electrophoresis of restriction fragments, ligation of DNA fragments and transformation of competent $E$. coli cells were carried out as described by Sambrook et al. (1989). The plasmid pMC6 was constructed in the binary vector pBI101.3 (Clontech Inc., Palo Alto, CA; Jefferson et al. 1987). Primers P36 (5'CCATAAGCTTGGATTTGTGGGGTGGGGAGC-3') and P21 (5'-ATCTCTAGAGCATTATGCATGCCAATGAGG-3') were used to amplify a 605 nucleotide promoter fragment. Amplification was performed for 30 cycles with an initial 3 min at $95^{\circ} \mathrm{C}$ and a final $5 \mathrm{~min}$ at $72^{\circ} \mathrm{C}$ in a PTC- 100 Programmable Thermal Controller (MJ Research Inc., Watertown, MA). Each cycle consisted of $30 \mathrm{~s}$ at $95^{\circ} \mathrm{C}$ followed by $1 \mathrm{~min}$ at $64^{\circ} \mathrm{C}$ and $1 \mathrm{~min}$ at $72^{\circ} \mathrm{C}$. The amplified promoter 
fragment was digested with HindIII-XbaI and subcloned into the HindIII-XbaI sites of the pBI101 to make a translational fusion with the GUS reporter gene. The plasmid pMC7 was also constructed in the binary vector pBI101.3 (Jefferson et al. 1987). Primers P36 (5'-CCATAAGCTTGGATTTGTGG GGTGGGGAGC-3') and P38 (5'-CGGATCCCCATTATGC GTGCCAATG-3’) were used to amplify a 606 nucleotide promoter fragment. Primer P38 has a single nucleotide difference to the native Shpx6b gene which has been underlined in the primer sequence. This nucleotide change alters an AUG codon in the $5^{\prime}$ leader sequence of the mRNA and removes a possible upstream translation initiator. Amplification was performed for 35 cycles with an initial $3 \mathrm{~min}$ at $95^{\circ} \mathrm{C}$ for denaturation and a final $5 \mathrm{~min}$ at $72^{\circ} \mathrm{C}$. Each cycle consisted of $30 \mathrm{~s}$ at $95^{\circ} \mathrm{C}$ followed by $1 \mathrm{~min}$ at $62^{\circ} \mathrm{C}$ and 1 min at $72^{\circ} \mathrm{C}$. The amplified promoter fragment was digested with HindIII-BamHI and subcloned into the HindIII-BamHI sites of the pBI101 to make a translational fusion with the GUS reporter gene.

\section{Plant transformation.}

Shpx6b promoter-GUS constructs in pBIN101.3 were transferred to Agrobacterium tumefaciens AGL1 by electroporation (Nagel et al. 1990). Transgenic tobacco plants, cv. Xanthi, were produced by the leaf disc transformation method (Horsch et al. 1985).

\section{$\beta$-Glucuronidase assays.}

The GUS activity in extracts from leaves was determined using the fluorometric assay with MUG (Sigma) as substrate as described by Jefferson (1987). Protein concentrations in the extracts were determined by the method of Bradford (1976). For histochemical GUS assays leaf strips were immersed in a reaction mixture containing $0.5 \mathrm{mg} \mathrm{ml}^{-1}$ XGluc (AGP Technologies, Upper Mount Gravatt, Queensland, Austrlia), 0.5 $\mathrm{mM}$ potassium ferricyanide, $1 \%(\mathrm{v} / \mathrm{v})$ Triton $\mathrm{X}-100$ in $50 \mathrm{mM}$ sodium phosphate buffer $(\mathrm{pH} 7.0)$ and incubated at $37^{\circ} \mathrm{C}$ overnight. The stained plant material was then cleared in $70 \%$ (v/v) ethanol.

\section{RT-PCR and Northern hybridization.}

Northern hybridization analysis was carried out on total RNA from tobacco leaves as described previously using a cDNA probe for PR1a (clone 119, Cornelissen et al. 1986) as described previously (Harrison et al. 1995). Total RNA for RT-PCR was isolated from young leaves of S. humilis cv. Paterson by the method of Manners and Scott (1985). RNA $(10 \mu \mathrm{g}$ in $5 \mu \mathrm{l})$ was mixed with $1 \mu \mathrm{l}\left(10 \mathrm{pmol} / \mathrm{ml}^{-1}\right)$ of primer P80 (5'-GTCATAGACACCATAAAATCTC-3'), incubated at $65^{\circ} \mathrm{C}$ for $5 \mathrm{~min}$ and then chilled on ice for $5 \mathrm{~min}$. To the reaction mix was added $3 \mu \mathrm{l}$ of dNTP (10 mM dNTP mix), $3 \mu \mathrm{l}$ of $500 \mathrm{mM}$ Tris- $\mathrm{HCl}$ (pH 8.3), $3 \mu \mathrm{l}$ of $80 \mathrm{mM} \mathrm{MgCl}_{2}, 3 \mu \mathrm{l} 700$ $\mathrm{mM} \mathrm{KCl}, 3 \mu \mathrm{l}$ of $10 \mathrm{mM}$ DTT, $1.5 \mu \mathrm{l}$ of RNAguard (Pharmacia, Uppsala, Sweden, $200 \mathrm{U} \mathrm{ml}^{-1}$ ), $2 \mu \mathrm{l}$ of $\mathrm{H}_{2} \mathrm{O}$ and $0.5 \mu \mathrm{l}$ of AMV reverse transcriptase $\left(25 \mathrm{U} \mathrm{ml}^{-1}\right)$. This mix was then incubated at $52^{\circ} \mathrm{C}$ for $60 \mathrm{~min}$. The reaction was stopped with $1 \mu \mathrm{l}$ of $0.5 \mathrm{M}$ EDTA. A sample of $5 \mu \mathrm{l}$ of the RT reaction was used to specifically amplify transcripts corresponding to the Shpx6a gene or the Shpx6b gene using either the primer P22 (5'-CTTTTATATATTATTGCATTGC-3') and P80 or the primer P23 (5'-CATAGCATATTCCTCATTGGC- $\left.3^{\prime}\right)$ and P80, respectively. Amplifications were performed in $50 \mu \mathrm{l}$ of $1 \times$ PCR buffer (Boehringer Mannheim, Indianapolis, IN), containing $200 \mathrm{mM}$ of each deoxyribonucleotide triphosphate, $300 \mathrm{nM}$ of each primer and $2.5 \mathrm{U}$ of Taq DNA polymerase (Boehringer Mannheim). The reaction was performed for 30 cycles with an initial $3 \mathrm{~min}$ at $95^{\circ} \mathrm{C}$ and a final $5 \mathrm{~min}$ at $72^{\circ} \mathrm{C}$. Each cycle consisted of $30 \mathrm{~s}$ at $95^{\circ} \mathrm{C}$ followed by $1 \mathrm{~min}$ at $48^{\circ} \mathrm{C}$ and $1 \mathrm{~min}$ at $72^{\circ} \mathrm{C}$. A second PCR amplification was required to obtain a discrete band of amplified DNA. An aliquot $(5 \mu \mathrm{l})$ of the original PCR reaction mix, after the initial 30 cycles, was used as the template for a second PCR amplification, performed as described before. The control reaction was carried out on $10 \mu \mathrm{g}$ of total RNA from each time interval. One microliter $\left(10 \mathrm{pmol}^{\mathrm{N}} \mathrm{l}^{-1}\right)$ of CAD-specific primer, CAD3F1 (5'-CGAAGCGATAC TTGACATCAG-3'), was used to produce the first strand cDNA using RT as described above. An aliquot of $5 \mu \mathrm{l}$ of the RT product was used to amplify transcripts corresponding to $\mathrm{CAD}$ using the primer CAD3F1 and primer CAD3.R2a (5'-TGATAAGCCTGGTTTGCATG-3'). Amplifications were performed as described before except that the annealing temperature was $56^{\circ} \mathrm{C}$.

\section{5' RACE.}

First-strand cDNA was produced using $10 \mu \mathrm{g}$ of total RNA and $1 \mu \mathrm{l}$ of primer P80 $\left(10 \mathrm{pmol} \mathrm{ml}^{-1}\right)$ as described earlier in the RT-PCR protocol. The reaction was stopped with $1 \mu \mathrm{l}$ of $0.5 \mathrm{M}$ EDTA, extracted with a phenol/chloroform mixture and precipitated with 2 volumes of EtOH and $1 / 10$ volume $3 \mathrm{M}$ sodium acetate $(\mathrm{pH} 4.8)$. The pellet was dried and resuspended in $100 \mu \mathrm{l}$ of sterile distilled $\mathrm{H}_{2} \mathrm{O}$ and passed through a GLASSMAX cDNA isolation spin cartridge to remove the excess of primer as described by the manufacturer (GIBCO BRL). A poly $\mathrm{C}$ tail was added to the cDNA with terminal transferase (TdT) as follows: $10 \mu \mathrm{l}$ of cDNA sample $(\sim 1 \mu \mathrm{g})$ was mixed with $6.5 \mu \mathrm{l}$ of sterile distilled $\mathrm{H}_{2} \mathrm{O}, 5.0 \mu \mathrm{l}$ of $5 \times$ tailing buffer $(1 \times$ buffer $=10 \mathrm{mM}$ Tris-HCl, $\mathrm{pH} 8.4,25 \mathrm{mM} \mathrm{KCl}, 1 \mathrm{mM} \mathrm{MgCl}_{2}$ ) and $2.5 \mu \mathrm{l}$ of 2 $\mathrm{mM}$ dCTP. This reaction mix was incubated at $94^{\circ} \mathrm{C}$ for 2 $\mathrm{min}$ and then chilled on ice for $1 \mathrm{~min}$. One microliter of TdT

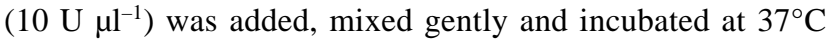
for $10 \mathrm{~min}$. The TdT was inactivated by heating for $10 \mathrm{~min}$ at $65^{\circ} \mathrm{C}$. The $\mathrm{dC}$-tailed cDNA was amplified using a nested primer P20 (5'-GCAATCATGGAAATGAAGGCG-3') and a 5' RACE anchor primer (GIBCO BRL). The reaction was performed for 30 cycles with an initial $3 \mathrm{~min}$ at $95^{\circ} \mathrm{C}$ and a final $5 \mathrm{~min}$ at $72^{\circ} \mathrm{C}$. Each cycle consisted of $30 \mathrm{~s}$ at $95^{\circ} \mathrm{C}$ followed by $1 \mathrm{~min}$ at $48^{\circ} \mathrm{C}$ and $1 \mathrm{~min}$ at $72^{\circ} \mathrm{C}$. A second PCR amplification was required to obtain a discrete band of amplified DNA. Five microliters of the original PCR reaction mix, after the initial 30 cycles, was used as the template for a second PCR amplification using primer P20 and a shortened version of the $5^{\prime} \mathrm{RACE}$ anchor primer P81 (5'GGCCACGCGTCGACTAGTAC-3'). The amplification was performed as described before. All amplifications were performed in $50 \mu \mathrm{l}$ of $1 \times$ PCR buffer (Boehringer Mannheim), $200 \mathrm{mM}$ of each deoxyribonucleotide triphosphate, $300 \mathrm{nM}$ of each primer and 2.5 U of Taq DNA polymerase (Boehringer Mannheim). The 5' RACE product was purified using the QIAquick PCR purification kit (Qiagen, Chatsworth, CA) as instructed by the manufacturer. 


\section{DNA sequencing.}

DNA sequencing was performed on denatured doublestranded DNA plasmid templates or denatured double-stranded PCR products using an Applied Biosystems (ABI, Foster City, CA) 373A automated sequencing instrument and the $\mathrm{ABI}$ PRISM DyeDeoxy Terminator Cycle sequencing kit or the ABI PRISM Dye Terminator Cycle sequencing ready reaction kit. Oligonucleotide primers used for PCR and DNA sequencing were synthesized on a Beckman Oligo 1000 DNA synthesizer. A 2.2-kbp 5' upstream region of the genomic clone $\lambda$ Shpx 6 (Curtis et al. 1995) was amplified using primers P56 (5'GCGTCGGAAGCTTATTGGCGTGAG-3') and P38. This product was digested with the restriction enzyme Sau3A and subcloned into the BamHI site of pUC18. These fragments were sequenced using the forward and reverse primers and primers designed from this sequence were used to obtain further sequence which allowed these fragments to be aligned. This approach was used to overcome problems encountered when sequencing the AT-rich regions of the promoter region. The sequence at the junction between the promoter and the GUS reporter in the plasmid pMC7 was verified using a specific primer which annealed to the complementary sequence of the $5^{\prime}$ end of the $\beta$-glucuronidase gene (5'-GCCCACAGGCCGTCGAG-3') and provided upstream sequence information. The $5^{\prime}$ RACE product was sequenced directly using a specific primer P82 (5'CTATGTTAAGGCACATG-3’) which differentiates the Shpx6b 5' RACE product from the Shpx6a 5' RACE product. RT-PCR products were sequenced directly using P80, P22, or P23 as sequencing primers to verify the origin of the transcripts.

\section{ACKNOWLEDGMENTS}

We are grateful to D. Guest of the University of Melbourne and P. Trevorrow of the Queensland Department of Primary Industries for providing the isolates of tobacco pathogens, to H. Kessmann of Ciba Ltd. for providing a sample of INA, to J. Bol of the State University of Leiden for providing a cDNA for PR1a, to K. Kazan and H. Bettenay for advice and assistance with plant transformation and maintenance, to A. Stines for the isolation of some of the RNA samples and to J. Nourse for assistance in DNA sequencing and analysis.

\section{LITERATURE CITED}

Aso, T., Conaway, J. W., and Conaway, R. C. 1994. Role of core promoter structure in assembly of the RNA polymerase II preinitiation complex. J. Biol. Chem. 269:26575-26583.

Baron, C., and Zambryski, P. C. 1995. The plant response in pathogenesis, symbiosis, and wounding: Variations on a common theme? Annu. Rev. Genet. 29:107-129.

Bradford, M. 1976. A rapid and sensitive method for the quantitation of microgram quantities of protein utilizing the principles of protein dye binding. Anal. Biochem. 72:248-254.

Bradley, D. J., Kjellbom, P., and Lamb, C. J. 1992. Elicitor- and woundinduced oxidative cross-linking of a proline-rich plant cell wall protein: A novel, rapid defence response. Cell 70:21-30.

Cook, D., Dreyer, D., Bonnet, D., Howell, M., Nony, E., and VandenBosch, K. 1995. Transient induction of a peroxidase gene in Medicago truncatula precedes infection by Rhizobium meliloti. Plant Cell 7:43-55.

Cornelissen, B. J. C., Hooft van Huijsduijnen, R. A. M., Van Loon, L. C., and Bol, J. F. 1986. Molecular characterization of messenger RNAs for 'pathogenesis-related' proteins $1 \mathrm{a}, 1 \mathrm{~b}$ and 1c, induced by TMV infection of tobacco. EMBO J. 5:37-40.

Creelman, R. A., Tierney, M. L., and Mullet, J. E. 1992. Jasmonic acid/methyl jasmonate accumulate in wounded soybean hypocotyls and modulate wound gene expression. Proc. Natl. Acad. Sci. USA
89:4938-4941.

Curtis, M. D., Nourse, J. P., and Manners J. M. 1995. Nucleotide sequence of a cationic peroxidase gene from the tropical forage legume Stylosanthes humilis. Plant Physiol. 108:1303-1304.

Durner, J., and Klessig, D. F. 1995. Inhibition of ascorbate peroxidase by salicylic acid and 2,6-dichloroisonicotinic acid, two inducers of plant defence responses. Proc. Natl. Acad. Sci. USA 92:11312-11316.

Epple, P., Apel, K., and Bohlmann, H. 1995. An Arabidopsis thaliana thionin gene is inducible via a signal transduction pathway different from that for pathogenesis-related proteins. Plant Physiol. 109:813820.

Farmer, E. E., and Ryan, C. A. 1990. Interplant communication: Airbourne methyl jasmonate induces synthesis of proteinase inhibitors in plant leaves. Proc. Natl. Acad. Sci. USA 87:7713-7716.

Farmer, E. E., and Ryan, C. A. 1992. Octadecanoid precursors of jasmonic acid activate the synthesis of wound-inducible proteinase inhibitors. Plant Cell 4:129-134.

Geballe, A. P., and Morris, D. R. 1994. Initiation codons within 5'leaders of mRNA as regulators of translation. TIBS 19:159-164.

Harrison, S. J., Curtis, M. D., McIntyre, C. L., Maclean, D. J., and Manners, J. M. 1995. Differential expression of peroxidase isogenes during the early stages of infection of the tropical forage legume Stylosanthes humilis by Colletotrichum gloeosporioides. Mol. PlantMicrobe Interact. 8:398-406.

Hindmann, T., Ebneth, M., Peña-Cortés, H., Sánchez-Serrano, J. J., Willmitzer, L., and Prat, S. 1992. General roles of abscisic acid and jasmonic acid in gene activation as a result of mechanical wounding. Plant Cell 4:1157-1170.

Horsch, R. B., Fry, J. E., Hoffmann, N. L., Eichholltz, D., Rogers, S. G., and Fraley, R. T. 1985. A simple and general method for transferring genes into plants. Science 227:1227-1231.

Irving, H. R., and Kuc, J. A. 1990. Local and systemic induction of peroxidase, chitinase and resistance in cucumber plants by $\mathrm{K}_{2} \mathrm{HPO}_{4}$. Physiol. Mol. Plant Pathol. 37:355-366.

Irwin, J. A. G., Trevorrow, P. R., and Cameron, D. F. 1984. Histopathology of compatible interactions involving biotypes of Colletotrichum gloeosporioides that cause anthracnose on Stylosanthes spp. Aust. J. Bot. 32:631-640.

Jefferson, R. A. 1987. Assaying chimeric genes in plants: The GUS gene fusion system. Plant Mol. Biol. Rep. 5:387-405.

Jefferson, R. A., Kavanagh, T. A., and Bevan, M. W. 1987. GUS fusions: beta-Glucuronidase as a sensitive and versatile gene fusion marker in plants. EMBO J. 6:3901-3907.

Jones, G. L., Bailey, J. A., and O'Connell, R. J. 1995. Sensitive staining of fungal extracellular matrices using colloidal gold. Mycol. Res. 99:567-573.

Joshi, C. P. 1987. An inspection of the domain between putative TATA box and translational start site in 79 plant genes. Nucleic Acids Res. 15:6643-6653.

Kawaoka, A., Kawamoto, T., Sekine, M., Yoshida, K., Takano, M., and Shinmyo, A. 1994. A cis-acting element and a trans-acting factor involved in the wound-induced expression of a horseradish peroxidase gene. Plant J. 6:87-97.

Keane, P. J., Limongiello, N., and Warren, M. A. 1988. A modified method for clearing and staining leaf-infecting fungi in whole leaves. Aust. Plant Pathol. 17:37-38.

Kerby, K., and Somerville, S. 1989. Enhancement of specific intercellular peroxidases following inoculation of barley with Erysiphe graminis f. sp. hordei. Physiol. Mol. Plant. Pathol. 35:323-337.

Kim, S.-R., Choi, J.-L., Costa, M. A., and An, Gynheung. 1992. Identification of G-box sequence as an essential element for methyljasmonate response of potato proteinase inhibitor II promoter. Plant Physiol. 99:627-631.

Kobayashi, A., Koguchi, Y., Kanzaki, H., Kajiyama, S., and Kawazu, K. 1994. A new type of antimicrobial phenolic produced by plant peroxidase and its possible role in the chemical defense systems against plant pathogens. Z. Naturforsch. 49:411-414.

Lazo, G. R., Stein, P. A., and Ludwig, R. A. 1991. A DNA transformation-competent Arabidopsis genomic library in Agrobacterium. Biotechnology 9:963-967.

Manners, J. M., and Scott, K. J. 1985 Reduced translatable messenger RNA activities in leaves of barley infected with Erysiphe graminis f. sp. hordei. Physiol. Plant Pathol. 26:297-308.

Mason, H. S., Dewald, D. B., and Mullet, J. E. 1993. Identification of a 
methyl-jasmonate responsive domain in soybean vspB promoter. Plant Cell 5:241-251.

Meyer, A., Miersch, O., Bittner, C., Dathe, W., and Sembdner, G. 1984. Occurrence of the plant growth regulator jasmonic acid in plants. J. Plant Growth Regul. 3:1-8.

Morris, D. R., Kakegawa, T., Kasper, R., and White, M. W. 1993. Polypyrimidine tracts and their binding proteins: Regulatory sites for posttranscriptional modulation of gene expression. Biochemistry 32: 2931-2937.

Murashige, T., and Skoog, F. 1962. A revised medium for rapid growth and biossays with tobacco tissue culture. Physiol. Plant. 15:473-497.

Nagel, R., Elliott, A., Masel, A., Birch, R. G., and Manners, J. M. 1990. Electroporation of binary Ti plasmid vector into Agrobacterium tumefaciens and Agrobacterium rhizogenes. FEMS Microbiol. Lett. 67: 325-328.

Ogle, H. J., Gowenlock, D. H., and Irwin, J. A. G. 1990. Infection of Stylosanthes guianensis and S. scabra by Colletotrichum gloeosporioides. Phytopathology 80:837-842.

Peng, M., and Kuc, J. 1992. Peroxidase-generated hydrogen peroxide as a source of antifungal activity in vitro and on tobacco leaf disks. Phytopathology 82:696-699.

Penninckx, I. A. M. A., Eggermont, K., Terras, F. R. G., Thomma, B. P. H. J., De Samblanx, G. W., Buchala, A., Metraux, J.-P., Manners, J. M., and Broekaert, W. F. 1996. Pathogen-induced systemic activation of a plant defensin gene in Arabidopsis follows a salicylic acid-independent pathway. Plant Cell 8:2309-2323.

Reinbothe, S., Reinbothe C., Lehmann, J., and Parthier, B. 1992. Differential accumulation of methyl jasmonate-induced mRNAs in response to abscisic acid and desiccation in barley (Hordeum vulgare). Physiol. Plant. 86:49-56.

Robin, C., and Guest, D. 1994. Characterisation of pathogenicity of Phytophthora parasitica isolates by stem and detached-leaf inoculations in four tobacco cultivars. N.Z. J. Crop Hortic. Sci. 22:159-166.

Ross, A. H., Manners, J. M., and Birch, R. G. 1995. Molecular cloning and characterisation of peroxidases from buffel grass (Cenchrus ciliaris L.). Plant Sci. 110:95-103.

Ryals, J., Uknes, S., and Ward, E. 1994. Systemic acquired resistance. Plant Physiol. 104:1109-1112.

Sambrook, J., Fritsch, E. F., and Maniatis, T. A. 1989. Molecular Cloning: A Laboratory Manual. 2nd ed. Cold Spring Harbor Laboratory, Cold Spring Harbor, NY.

Schindler, U., Menkeus, A. E., Beckmann, H., Ecker, J. E., and Cashmore, A. R. 1992. Heterodimerization between light-regulated and ubiquitously expressed Arabidopsis GBF bZip proteins. EMBO J. 11:1261-1273.

Sembdner, G., and Parthier, B. 1993. The biochemistry and the physiological and molecular actions of jasmonates. Annu. Rev. Plant Physiol. Plant Mol. Biol. 44:569-589.
Sherf, B. A., Bajar, A. M., and Kolattukudy, P. E. 1993. Abolition of an inducible highly anionic peroxidase activity in transgenic tomato. Plant Physiol. 101:201-208.

Staiger, D., Kaulen, H., and Schell, J. 1989. A CACGTG motif of Antirrhinum majus chalcone synthase promoter is recognized by an evolutionarily conserved nuclear protein. Proc. Natl. Acad. Sci. USA 86:6930-6934.

Thordal-Christensen, H., Brandt, J., Cho, B. H., Ramussen, S. K., Gregersen, P. L., Smedegaard-Peterson, V., and Collinge, D. B. 1992. cDNA cloning and characterisation of two barley peroxidase transcripts induced differentially by the powdery mildew fungus Erysiphe graminis. Physiol. Mol. Plant. Pathol. 40:395-409.

Tyson, H. 1992. Relationships among amino acid sequences of animal, microbial, and plant peroxidases. Theor. Appl. Genet. 84:643-655.

Uknes, S., Mauch-Mani, B., Moyer, M., Potter, S., Williams, S., Dincher, S., Chandler, D., Slusarenko, A., and Ryals, J. 1992. Acquired resistance in Arabidopsis. Plant Cell 4:645-656.

Uknes, S., Dencher, S., Friedrich, L., Negrotto, D., Williams, S., Thompson-Taylor, H., Potter, S., Ward, E., and Ryals, J. 1993. Regulation of pathogenesis related protein-1a gene expression in tobacco. Plant Cell 5:159-169.

Vernooij, B., Friedrich, L., Goy, P. A., Staub, T., Kessmann, H., and Ryals, J. 1995. 2,6-Dichloroisonicotinic acid-induced resistance to pathogens without the accumulation of salicylic acid. Mol. PlantMicrobe Interact. 8:228-234.

Walter, M. H. 1992. Regulation of lignification in defense. Pages 327352 in: Genes Involved in Plant Defense. T. Boller and F. Meins, eds. Springer-Verlag, New York.

Weis, L., and Reinberg, D. 1992. Transcription by RNA polymerase II: Initiator-directed formation of transcription-competent complexes. FASEB J. 6:3300-3309.

Williams, M. E., Foster, R., and Chua, N.-H. 1992. Sequences flanking the hexameric G-box core CACGTG affect the specificity of protein binding. Plant Cell 4:485-496.

Xu, Y., Chang, P.-F. L., Liu, D., Narasimhan, M. L., Raghothama, K. G., Hasegawa, P. M., and Bressan, R. A. 1994. Plant defense genes are synergistically induced by ethylene and methyl jasmonate. Plant Cell 6:1077-1085.

Ye, X. S., Pan, S. Q., and Kuc, J. 1990. Association of pathogenesisrelated proteins and activities of peroxidase, $\beta$-1,3-glucanase and chitinase with systemic induced resistance to blue mould of tobacco but not to systemic tobacco mosaic virus. Physiol. Mol. Plant Pathol. 36:523-531.

Zhu, Q., Maher, E. A., Masoud, S., Dixon, R. A., and Lamb, C. J. 1994. Enhanced protection against fungal attack by constitutive coexpression of chitinase and glucanase genes in transgenic tobacco. Biotechnology 12:807-812. 